\title{
Preservative Effect of Novel Combined Treatment with Electrolyzed Active Water and Lysozyme Enzyme to Increase the Storage Life of Vacuum-Packaged Carp
}

\author{
Péter Palotás $\mathbb{D}^{\mathbb{D}},{ }^{1}$ Péter Palotás Jr., ${ }^{2}$ Gábor Jónás, ${ }^{1}$ József Lehel $\mathbb{D}^{0},{ }^{3}$ and László Friedrich ${ }^{1}$ \\ ${ }^{1}$ Szent István University, Faculty of Food Science, Department of Refrigeration and Livestock's Products Technology, \\ Ménesi Street 43-45, Budapest 1118, Hungary \\ ${ }^{2}$ Technical University of Denmark, National Institute for Aquatic Resources, Kemitorvet, 2800, Kgs. Lyngby, Denmark \\ ${ }^{3}$ University of Veterinary Medicine, Department of Food Hygiene, István Street 2, Budapest 1078, Hungary \\ Correspondence should be addressed to Péter Palotás; palotas.peter@etk.szie.hu
}

Received 22 August 2019; Revised 8 December 2019; Accepted 13 January 2020; Published 17 February 2020

Academic Editor: Luis Patarata

Copyright (c) 2020 Péter Palotás et al. This is an open access article distributed under the Creative Commons Attribution License, which permits unrestricted use, distribution, and reproduction in any medium, provided the original work is properly cited.

\begin{abstract}
In the present study, common carp (Cyprinus carpio), a highly valuable worldwide commercial fish species, was used as a model. One sample group of fresh, skin-on carp fillets was placed in a bath of acidic electrolyzed oxidizing (AEO) water containing a solution of $100 \mathrm{mg} / \mathrm{kg}$ chloride ion concentration for 5 minutes. Another sample group was treated with acidic electrolyzed water and $0.5 \%$ lysozyme enzyme solution. Another set of samples were washed after the AEO water treatment. Within the study, a storage test was performed to examine the effect of the new combined treatment on the samples' shelf-life and quality while kept at $2^{\circ} \mathrm{C}$. During the storage period, chemical (chlorate) and microbiological (TVC, mesophilic anaerobic plate count, and Enterobacteriaceae count) tests and sensory evaluation were conducted. The combination of AEO water and lysozyme enzyme showed additional bactericidal efficacy on the surface of the carp fillets, which has never been reported before. Both the AEO water and the combined treatment effectively increased the shelf life of the samples, causing 2.4-3.1 log CFU/g difference compared to the control by the end of the 7-day storage. The measured residual chlorate content exceeded the legal threshold, but washing the samples resulted in values below the theoretical threshold limit. The applied preservation methods did not have an adverse effect on the organoleptic properties of the samples.
\end{abstract}

\section{Introduction}

Increasing the shelf life of a product, the safe manufacture of food products, and food safety are some of the biggest challenges of the food industry. An estimated $25 \%$ of food products become unfit for consumption due to microbial deterioration [1]. The short shelf life of fresh fish is caused by postmortem biochemical reactions and deterioration caused by microbes. Common carp (Cyprinus carpio) is the most important fish species of temperate-zone freshwater aquacultures $[2,3]$. Due to the climate, water temperatures and the microflora of these waters the microorganisms count on the carps' integument, gills and in their digestive system is higher compared to that of marine or cold water species [4]. There are traditional chemical and physical procedures for the preservation of fish; however, consumers have a legitimate demand to consume minimally processed foods, with the least change in nutritional value and organoleptic qualities [5].

Electrolyzed oxidizing (EO) water is a novel antimicrobial agent developed in Japan; but its industrial application is becoming increasingly widespread among food manufacturers [6]. It is relatively easy to produce. $\mathrm{NaCl}$ is dissolved in deionized water; then, the solution is electrolyzed in a closed cavity. As a result, acidic water ( $\mathrm{pH}$ 2.3-2.7 and redox potential $[\mathrm{ORP}]>1100 \mathrm{mV}$ ) is generated on the anode side of the membrane-separated space, in which chloride ion $\left(\mathrm{Cl}^{-}\right)$, hypochlorous acid ( $\left.\mathrm{HOCl}\right)$, and diluted hydrochloric acid are concentrated [7]. On the other side of the membrane-separated space, alkaline water ( $\mathrm{pH}$ 10-11.5 and ORP $<800 \mathrm{mV}$ ) is generated, in which sodium ion $\left(\mathrm{Na}^{+}\right)$ and sodium hydroxide $(\mathrm{NaOH})$ are concentrated [8]. Acidic 
electrolyzed water (AEO) is an effective antimicrobial agent, but it can also be used to remove other kinds of contaminants [9]. The disinfection properties of AEW are mainly ensured by the high concentration of $\mathrm{HOCl}$ forming chlorine $\left({ }^{\circ} \mathrm{Cl}\right)$ and hydroxyl $\left({ }^{\circ} \mathrm{OH}\right)$ radicals $[10-12]$. Due to its high oxidative reduction potential, EO water acts as an oxidative agent disrupting cellular functions, including DNA synthesis, permeable membrane structure, metabolic enzymes, and electron transport systems [13].

EO water has the following advantages. It is an effective disinfectant, easy to operate with, and relatively cheap, and due to the fast termination of the ionic state, it is also environmentally friendly. However, the main advantage of EO water is its safety [6]. Although EO water generated on the anode side of the membrane is a strong acid, it differs from hydrochloric acid or sulphuric acid as it is not corrosive on the skin, the mucous membrane, or other organic materials. According to previous research studies, the effect of EO water was significantly limited by the mucin-type glycoprotein layer covering the body of fish $[14,15]$; therefore, it is suggested to develop a combined preservation method in which the synergistic advantages of different treatments are reflected, but the organoleptic properties of fish are not changed. The application of EO water combined with lysozyme as another antimicrobial agent is an approach that has never been tested before.

Lysozyme is a $14.6 \mathrm{kDa}$ protein produced by mammals, which has long been known as an antimicrobial agent. As an enzyme, it is mainly effective against Gram-positive bacteria and less so against Gram-negative ones by breaking down the $\beta(1-4)$ glycosidic linkages of murein [16]. In the food industry, it is used to extend the shelf life of cheese, sea foods, fruits, and vegetables [17], but it is usually combined with other bactericidal agents. In [18], the authors studied the synergistic effect of lysozyme and chitooligosaccharide on raw pork and raw minced pork. This combined treatment resulted in the total elimination of Escherichia coli, Pseudomonas fluorescens, and Bacillus cereus and the reduction of Staphylococcus aureus in meat. In [19], the authors used lysozyme combined with nisin to decrease the number of meat spoilage bacteria (Brochothrix thermosphacta B2 and Carnobacterium sp. 845). The researchers found that the combination would have a better antimicrobial effect on the treated fat and lean tissue than their separate use. The main limitation for the general use of lysozyme is that although it is efficient against Gram-positive bacteria, it is much less so against Gram-negative ones; therefore, it is beneficial to use it in combination with other substances [20]. Research indicates that the effect of lysozyme could be extended to Gram-negative bacteria and the lysozyme's functional properties could be improved by a lysozyme-galactomannan conjugation [21]. Lysozyme's enzyme activity can also be enhanced by certain substances, including EDTA and butylparaben, and by some natural antimicrobial agents $[22,23]$. However, these chemicals are not suitable for food industry applications.

Research on the antimicrobial effect of EO water has not yet discussed the residual chlorate and chlorate derivatives on the treated foods. Due to the consumption of chlorate and perchlorate in food, the concentration of hemoglobin and hematocrit and the decrease of red blood cell count were detected; furthermore, thyroid dysfunction was observed $[24,25]$. Since no specific maximum residue limit (MRL) was fixed under Reg. (EC) No. 396/2005, the default MRL of $0.01 \mathrm{mg} / \mathrm{kg}$ is applicable for chlorate to all food products included in Annex I to that regulation [26]. However, according to the scientific opinion of EFSA about the risks for public health related to the presence of chlorate in food, a theoretical $0.7 \mathrm{MRL}$ would not change the potential risks related to chlorate [27].

This study aims to investigate the impact of the combination of AEO water and lysozyme on the shelf life of carp fillets to determine whether the combined treatment has an additional effect compared to using AEO alone, as well as evaluating whether the washing of the samples after the AEO water treatment can sufficiently reduce the chlorate and perchlorate levels along with the assessment of the capability of the application lysozyme enzyme to compensate loss of effectiveness resulting from the washing step.

\section{Materials and Methods}

2.1. Sample Preparation. In this study, scaly common carps (Cyprinus carpio) of average body weight of $2.5 \mathrm{~kg}$ were purchased from a local aquaculture, Öko 2000 Ltd. in Akasztó, Hungary. Carps were transported to the fish slaughtering and processing facility and kept alive for 48 hours in a $15^{\circ} \mathrm{C}$ pool with continuous air-spraying and daily $20 \%$ water change until the time of sample preparation. Overall, 38 carps were used for the experiments. The fish were stunned with electricity $(300 \mathrm{~mA}, 50 \mathrm{~V}$, and $50 \mathrm{~Hz})$ for 30 seconds, slaughtered, bled, scaled, and gutted.

The carcasses were filleted then sliced into $100 \mathrm{~g}$ pieces of $6 \times 14 \times 2 \mathrm{~cm}$ on average and separated into six groups. For the control group, untreated slices were vacuum packaged in $180 \times 230 \mathrm{~mm}, 90 \mu \mathrm{m}$ thick PP foils. The second group was washed with tap water. The third group was treated by acidic $(\mathrm{pH} 2.5)$ electrolyzed active water with $100 \mathrm{mg} / \mathrm{kg}$ chlorine ion concentration. The active water was produced with a REDO Pure 250 active water generator.

The fish fillets were put into 25 liters of active water for five minutes and were stirred every minute (AEO). The fourth group was treated by acidic electrolyzed active water and then washed with tap water (AEO Washed). The fifth group was placed in acidic electrolyzed water and then their surface was sprayed with a $0.5 \%$ lysozyme enzyme solution $(\mathrm{AEO}+L)$. The sixth group was placed in acidic electrolyzed water and washed with tap water, followed by treatment with lysozyme enzyme solution (AEO Washed $+L$ ). The samples were drained and vacuum packaged in $180 \times 230 \mathrm{~mm}, 90 \mu \mathrm{m}$ thick PP foils and then stored at $2^{\circ} \mathrm{C}$ among ice flakes. Five samples per group were prepared for microbiological analysis, and twenty-five samples per treatment for sensory evaluation.

Microbiological analysis was conducted on days $0,1,2,4$, and 7. Residual chlorate and perchlorate tests were performed on days 0 and 4 , and sensory evaluation was performed on day 0 . 
2.2. Microbiological Analyses. Microbiological tests were carried out on 0,1 , and 4 day of storage. Total viable count (TVC) was determined according to the ISO 4833-1:2013 by pour-plating with PC agar and incubating the plates at $30 \pm 1^{\circ} \mathrm{C}$ for $72 \pm 3 \mathrm{~h}$. Enterobacteriaceae count was determined according to the ISO 21528-2:2017 standard, by pour-plating with VRBG agar, incubating the plates at $37 \pm 1^{\circ} \mathrm{C}$ for $24 \pm 2 \mathrm{~h}$, and carrying out glucose fermentation and oxidase presence tests as confirmation. Mesophilic anaerobic plate count was determined by pour-plating with RCM media and incubating in $\mathrm{CO}_{2}$ atmosphere in the BACT-R Plus anaerobic system (Sobioda, France) at $30 \pm 1^{\circ} \mathrm{C}$ for $72 \pm 3 \mathrm{~h}$. The results were expressed in $\log _{10} \mathrm{CFU} / \mathrm{g}$.

\subsection{Residual Chlorate and Perchlorate Content. The washed} control samples and samples treated with acid water were examined for residual chlorate and perchlorate content on days 0 and 4 of storage. To determine the chlorate and perchlorate content $5 \pm 0.05 \mathrm{~g}$, homogenized samples were put into $50 \mathrm{ml}$ centrifuge tubes, and isotope-labeled chlorate internal standards (ISTD) were added to it. Five millilitres of water with $1 \%$ acetic acid and $20 \mathrm{ml}$ acetonitrile were added to the samples. Then, the samples were vigorously shaken by hand for 1 minute and put into an ultrasound bath for 5 minutes afterwards. Following the ultrasound bath, the samples were centrifuged at $4500 \mathrm{rpm}$ for 10 minutes. One $\mathrm{mL}$ of the extract was put into a disposable autosampler vial and stored at $0-5^{\circ} \mathrm{C}$ until measurement. The chlorine content of the samples was assayed in triplicate by the LC-MS/ MS method [28]. The results were expressed in $\mathrm{mg} / \mathrm{kg}$.

2.4. Sensory Evaluation. The purpose of the organoleptic examination was to determine whether the treatments caused an immediate change in the sensory properties of the fish meat. Twenty-five panelists (aged 25-50 years) familiar with sensory evaluation procedures were recruited. The sensory evaluation was conducted based on general appearance, color, odor, texture, and flavor using a 5-point hedonic scale: 1 , dislike extremely to 5 , like extremely. For sensory evaluation of general appearance, color, odor, and texture, fish samples of each treatment were removed from cold storage and equilibrated at room temperature $\left(25^{\circ} \mathrm{C}\right)$ for $1 \mathrm{~h}$ before evaluation. For the evaluation of flavor, the fillets were put on an oiled baking pan and then fried for 10 minutes at $180^{\circ} \mathrm{C}$ in a Lainox VE 051P Combi Oven-Direct Steam equipment. Afterwards, the fillets were left in the oven for an additional 3 minutes until the sensory evaluation test started. The outcome of the microbiological storage test for the sample series was unknown, so for food safety reasons, the study was performed only on day 0 .

2.5. Statistical Analysis. The statistical analysis of the results was performed with SPSS Statistics 22.0 (IBM Corp., Armonk, NY). Data were expressed as mean \pm SD. Bacterial numbers in CFU/g were transformed into $\log _{10}$ for statistical analysis. The data of microbiological analysis, sensory evaluation, and chlorate and perchlorate content were expressed as mean \pm SD. Significant differences in bacterial populations and sensory scores were evaluated at $p<0.05$ by analysis of variance (ANOVA) and Duncan's multiple range test.

\section{Results and Discussion}

3.1. Microbial Analyses. The effects of AEO water $(\mathrm{pH}=2.5$, free available chlorine content of $100 \mathrm{mg} / \mathrm{l}$ ) and its combined treatment with $0.5 \%$ lysozyme enzyme solution on TVC, Enterobacteriaceae count, and anaerobic mesophilic count were examined on days $0,1,2,4$, and 7 of storage. As shown in Table 1, the control samples TVC clearly reflects the shortness of the fish fillet's shelf life in a normal vacuum package, reaching the $10^{7} \mathrm{CFU} / \mathrm{g}$ value on day 2 . $N=10^{7} \mathrm{CFU} / \mathrm{g}$ is the value after which signs of deterioration start to appear [29], so it can be considered as the threshold of microbial spoilage.

In case of the unwashed samples, both AEO water and the combined treatment resulted immediately in a significant $(p<0.05)$ reduction $(2.0-2.5$ logs $)$ of the TVC compared to the control sample. This reduction was maintained during the storage. These results are in agreement with the data obtained following AEO water treatment of American shad [30] and common carp [4] samples reporting 1.5-2.0 $\log \mathrm{CFU} / \mathrm{g}$ reduction in TVC during the storage. Only a minor additional reducing effect was observed at the combined treatment until day 7 of storage. Although the optimum activity of lysozyme enzyme was reported to be at a $\mathrm{pH}$ of 5.3-6.4 [31], it has been demonstrated to be active over a wider $\mathrm{pH}$ range of 4-10 [32].

The immediate effect of lysozyme caused about 0.5 $\log \mathrm{CFU} / \mathrm{g}$ difference between the plate counts treated with electrolyzed oxidizing water and the ones with the combined treatment. This difference further increased during the seven days of storage. Washing the samples after the AEO water treatment did not result in the increase of the effectiveness of lysozyme enzyme. This allows the conclusion that the acidic conditions of the AEO water did not influence the potency of the lysozyme enzyme.

Washing the samples after the AEO water treatment showed to retain its effectiveness as significant differences were measured compared to the nonwashed samples. However, the EOW treatment followed by washing also successfully increased the shelf life of the carp samples, maintaining 1.4-2.2 log CFU/g difference compared to the control group. The contrast between the washed and unwashed samples shows the substantial role of the residual chlorine on the surface after the treatment, which was partially removed by washing. In [33], the authors reported the chlorate loss over time as one of the major limiting factor of AEO water mainly caused by the evaporation of dissolved chlorine gas. However, in closed vacuum packaged conditions, the chlorate loss is significantly reduced, increasing its bactericidal activity. Overall, all treatments have significantly improved the shelf life of the samples compared to the control group, the most effective treatment resulting in more than 5-day increase in shelf life. 
TABLE 1: Effects of washing, acidic electrolyzed oxidizing water, and lysozyme treatments on the total viable count of carp samples.

\begin{tabular}{|c|c|c|c|c|c|}
\hline \multirow{2}{*}{ Treatment } & \multicolumn{5}{|c|}{ Total viable count of carp samples $(\log 10 \mathrm{CFU} / \mathrm{g} \pm \mathrm{SD})$} \\
\hline & Day 0 & Day 1 & Day 2 & Day 4 & Day 7 \\
\hline Control & $4.86 \pm 0.17^{\mathrm{a}}$ & $6.22 \pm 0.42^{\mathrm{a}}$ & $7.11 \pm 0.26^{\mathrm{a}}$ & $8.83 \pm 0.09^{\mathrm{a}}$ & $9.24 \pm 0.13^{\mathrm{a}}$ \\
\hline Washed & $3.93 \pm 0.31^{\mathrm{b}}$ & $5.36 \pm 0.22^{\mathrm{b}}$ & $6.21 \pm 0.33^{\mathrm{b}}$ & $8.22 \pm 0.26^{\mathrm{b}}$ & $8.47 \pm 0.21^{\mathrm{b}}$ \\
\hline AEO & $2.87 \pm 0.12^{\mathrm{d}}$ & $4.10 \pm 0.29^{\mathrm{d}}$ & $4.78 \pm 0.23^{\mathrm{d}}$ & $6.27 \pm 0.26^{\mathrm{d}}$ & $6.76 \pm 0.26^{\mathrm{c}}$ \\
\hline AEO washed & $3.43 \pm 0.25^{\mathrm{c}}$ & $4.77 \pm 0.55^{\mathrm{c}}$ & $5.63 \pm 0.36^{\mathrm{c}}$ & $6.63 \pm 0.20^{c}$ & $7.04 \pm 0.27^{\mathrm{c}}$ \\
\hline $\mathrm{AEO}+L$ & $2.34 \pm 0.19^{\mathrm{e}}$ & $3.39 \pm 0.13^{\mathrm{e}}$ & $4.15 \pm 0.22^{\mathrm{e}}$ & $5.39 \pm 0.26^{\mathrm{e}}$ & $6.10 \pm 0.36^{\mathrm{d}}$ \\
\hline AEO washed $+L$ & $2.93 \pm 0.42^{\mathrm{d}}$ & $4.24 \pm 0.31^{\mathrm{d}}$ & $4.77 \pm 0.38^{\mathrm{cd}}$ & $6.00 \pm 0.13^{\mathrm{d}}$ & $6.36 \pm 0.22^{\mathrm{d}}$ \\
\hline
\end{tabular}

${ }^{a}$ Mean \pm SD, $n=5$; values in the same column for each attributes followed by a different letter (a-d) are significantly different $(p<0.05)$. AEO: acidic electrolyzed oxidizing (AEO) water $(100 \mathrm{mg} / \mathrm{kg}$ ) treatment for $5 \mathrm{~min}$. AEO washed: acidic electrolyzed oxidizing water treatment for $5 \mathrm{~min}$ followed by washing. AEO $+L$ : electrolyzed oxidizing water treatment for $5 \mathrm{~min}$ followed by spraying of $0.5 \%$ lysozyme enzyme $(L)$ solution. AEO washed $+L$ : electrolyzed oxidizing water treatment for $5 \mathrm{~min}$ followed by washing and spraying of $0.5 \%$ lysozyme enzyme solution on the total viable count of carp samples.

TABLE 2: Effects of washing, acidic electrolyzed oxidizing water, and lysozyme treatments on the mesophilic anaerobic plate count of carp samples.

\begin{tabular}{|c|c|c|c|c|c|}
\hline \multirow{2}{*}{ Treatment } & \multicolumn{5}{|c|}{ Mesophilic anaerobic plate count of carp samples $(\log 10 \mathrm{CFU} / \mathrm{g} \pm \mathrm{SD})$} \\
\hline & Day 0 & Day 1 & Day 2 & Day 4 & Day 7 \\
\hline Control & $4.39 \pm 0.20^{\mathrm{a}}$ & $5.75 \pm 0.17^{\mathrm{a}}$ & $6.51 \pm 0.27^{\mathrm{a}}$ & $6.55 \pm 0.26^{\mathrm{a}}$ & $7.29 \pm 0.15^{\mathrm{a}}$ \\
\hline Washed & $3.85 \pm 0.22^{\mathrm{b}}$ & $5.41 \pm 0.12^{\mathrm{a}}$ & $6.03 \pm 0.17^{\mathrm{b}}$ & $6.75 \pm 0.28^{\mathrm{a}}$ & $7.31 \pm 0.50^{\mathrm{a}}$ \\
\hline AEO & $2.76 \pm 0.58^{\mathrm{cd}}$ & $3.30 \pm 0.43^{\mathrm{c}}$ & $4.30 \pm 0.33^{\mathrm{d}}$ & $5.14 \pm 0.40^{\mathrm{c}}$ & $5.89 \pm 0.05^{\mathrm{b}}$ \\
\hline AEO washed & $3.16 \pm 0.57^{\mathrm{c}}$ & $4.11 \pm 0.34^{\mathrm{b}}$ & $4.63 \pm 0.18^{c}$ & $5.86 \pm 0.08^{\mathrm{b}}$ & $6.92 \pm 0.11^{\mathrm{a}}$ \\
\hline $\mathrm{AEO}+L$ & $2.29 \pm 0.26^{\mathrm{d}}$ & $2.95 \pm 0.26^{\mathrm{c}}$ & $3.61 \pm 0.26^{\mathrm{e}}$ & $4.57 \pm 0.21^{\mathrm{d}}$ & $5.28 \pm 0.16^{\mathrm{c}}$ \\
\hline AEO washed $+L$ & $2.84 \pm 0.08^{c}$ & $4.07 \pm 0.55^{\mathrm{b}}$ & $4.23 \pm 0.15^{\mathrm{d}}$ & $5.21 \pm 0.09^{c}$ & $5.86 \pm 0.12^{b}$ \\
\hline
\end{tabular}

${ }^{\mathrm{a}}$ Mean $\pm \mathrm{SD}, n=5$; values in the same column for each attribute followed by a different letter (a-d) are significantly different $(p<0.05)$. AEO: acidic electrolyzed oxidizing (AEO) water $(100 \mathrm{mg} / \mathrm{kg}$ ) treatment for $5 \mathrm{~min}$. AEO washed: acidic electrolyzed oxidizing water treatment for $5 \mathrm{~min}$ followed by washing. $\mathrm{AEO}+L$ : electrolyzed oxidizing water treatment for $5 \mathrm{~min}$ followed by spraying of $0.5 \%$ lysozyme enzyme $(L)$ solution. AEO washed $+L:$ electrolyzed oxidizing water treatment for $5 \mathrm{~min}$ followed by washing and spraying of $0.5 \%$ lysozyme enzyme solution on the total viable count of carp samples.

TABLE 3: Effects of washing, acidic electrolyzed oxidizing water, and lysozyme treatments on the Enterobacteriaceae count of carp samples.

\begin{tabular}{|c|c|c|c|c|c|}
\hline \multirow{2}{*}{ Treatment } & \multicolumn{5}{|c|}{ Enterobacteriaceae count of carp samples $(\log 10 \mathrm{CFU} / \mathrm{g} \pm \mathrm{SD})$} \\
\hline & Day 0 & Day 1 & Day 2 & Day 4 & Day 7 \\
\hline Control & $3.49 \pm 0.30^{\mathrm{a}}$ & $4.58 \pm 0.28^{\mathrm{a}}$ & $6.16 \pm 0.53^{\mathrm{a}}$ & $7.41 \pm 0.26^{\mathrm{a}}$ & $8.04 \pm 0.12^{\mathrm{a}}$ \\
\hline Washed & $2.75 \pm 0.39^{\mathrm{b}}$ & $4.36 \pm 0.18^{\mathrm{a}}$ & $5.99 \pm 0.20^{\mathrm{a}}$ & $6.98 \pm 0.05^{\mathrm{a}}$ & $7.93 \pm 0.12^{\mathrm{a}}$ \\
\hline AEO & $1.72 \pm 0.03^{\mathrm{d}}$ & $2.79 \pm 0.20^{\mathrm{bc}}$ & $4.20 \pm 0.41^{\mathrm{b}}$ & $4.53 \pm 0.48^{\mathrm{c}}$ & $4.66 \pm 0.28^{\mathrm{d}}$ \\
\hline AEO washed & $2.33 \pm 0.03^{\mathrm{c}}$ & $3.05 \pm 0.40^{\mathrm{b}}$ & $4.26 \pm 0.16^{\mathrm{b}}$ & $5.49 \pm 0.35^{\mathrm{b}}$ & $6.98 \pm 0.32^{\mathrm{b}}$ \\
\hline $\mathrm{AEO}+L$ & $1.30 \pm 0.32^{\mathrm{e}}$ & $2.16 \pm 0.28^{\mathrm{d}}$ & $3.03 \pm 0.13^{c}$ & $3.73 \pm 0.10^{\mathrm{d}}$ & $4.58 \pm 0.27^{\mathrm{d}}$ \\
\hline AEO washed $+L$ & $1.89 \pm 0.49^{\mathrm{d}}$ & $2.61 \pm 0.30^{c}$ & $4.01 \pm 0.29^{b}$ & $4.76 \pm 0.56^{\mathrm{d}}$ & $5.06 \pm 0.43^{\mathrm{d}}$ \\
\hline
\end{tabular}

${ }^{a}$ Mean \pm SD, $n=5$; values in the same column for each attributes followed by a different letter (a-d) are significantly different $(p<0.05)$. AEO: acidic electrolyzed oxidizing (AEO) water $(100 \mathrm{mg} / \mathrm{kg}$ ) treatment for $5 \mathrm{~min}$. AEO washed: acidic electrolyzed oxidizing water treatment for $5 \mathrm{~min}$ followed by washing. AEO + $L$ : electrolyzed oxidizing water treatment for $5 \mathrm{~min}$ followed by spraying of $0.5 \%$ lysozyme enzyme $(L)$ solution. AEO washed $+L$ : electrolyzed oxidizing water treatment for $5 \mathrm{~min}$ followed by washing and spraying of $0.5 \%$ lysozyme enzyme solution on the total viable count of carp samples.

The same trends were observed at the results of mesophilic anaerobic plate count (Table 2). Application of AEO water caused decrease in the total plate count by more than 1 order of magnitude during the storage. It is consistent with the results of previous studies performed on tilapia [34] and Atlantic salmon [35] inoculated with E. coli and L. monocytogenes, where a reduced number of bacteria were recorded due to the effect of active water on the surface of fish flesh and skin. Compared to the TVC, mesophilic anaerobic bacteria reached considerably lower plate counts. It is assumed that storage conditions influenced the differences in TVC and anaerobic mesophilic plate count changes. Since the samples were stored at $0-2^{\circ} \mathrm{C}$, this favored the psychrotrophic microbes. Presumably, the proportion of anaerobic microbes in the samples was less cold-loving, so their growth during storage was slower compared to the TVC.

As shown in Table 3, AEO water immediately resulted in a $1.78 \log \mathrm{CFU} / \mathrm{g}$ reduction in the Enterobacteriaceae count.

Although lysozyme enzyme was reported to have lower effectiveness against Gram-negative microorganisms [17], the application of lysozyme enzyme in the combined treatment showed additional bactericidal effect compared to the AEO water treatment. Furthermore, the application of lysozyme enzyme has sufficiently compensated the loss of effectiveness, originating from the washing step after AEO water treatment as, in general, no significant difference was observed between the AEO and AEO washed $+L$ groups. 
TABLE 4: Measurement of residual chlorate and perchlorate concentration of unwashed and washed samples following treatment.

\begin{tabular}{lcc}
\hline & Chlorate and perchlorate concentration $(\mathrm{mg} / \mathrm{kg} \pm \mathrm{SD})$ & \\
\hline & Chlorate & Perchlorate \\
Control & $0.011 \pm 0.002$ & $<0.01$ \\
Washed & $0.106 \pm 0.011$ & $<0.01$ \\
AEO & $0.822 \pm 0.086$ & $0.014 \pm 0.001$ \\
AEO washed & $0.277 \pm 0.046$ & $0.012 \pm 0.001$ \\
AEO $+L$ & $0.669 \pm 0.016$ & $0.019 \pm 0.002$ \\
AEO washed $+L$ & $0.291 \pm 0.017$ & $0.015 \pm 0.002$ \\
\hline
\end{tabular}

${ }^{\mathrm{a}}$ Mean $\pm \mathrm{SD}, n=3$ AEO: acidic electrolyzed oxidizing (AEO) water $(100 \mathrm{mg} / \mathrm{kg})$ treatment for $5 \mathrm{~min}$. AEO washed: acidic electrolyzed oxidizing water treatment for $5 \mathrm{~min}$ followed by washing. AEO $+L$ : electrolyzed oxidizing water treatment for $5 \mathrm{~min}$ followed by spraying of $0.5 \%$ lysozyme enzyme $(L)$ solution. AEO washed $+L$ : electrolyzed oxidizing water treatment for $5 \mathrm{~min}$ followed by washing and spraying of $0.5 \%$ lysozyme enzyme solution on the total viable count of carp samples.

TABLE 5: Effects of washing, acidic electrolyzed oxidizing water, and lysozyme treatments on the sensory properties of carp samples.

\begin{tabular}{|c|c|c|c|c|c|}
\hline \multirow{2}{*}{ Treatment } & \multicolumn{5}{|c|}{ Sensory scores of the carp samples } \\
\hline & General appearance & Color & Odor & Texture & Flavor \\
\hline Control & $3.96 \pm 0.73^{\mathrm{a}}$ & $3.92 \pm 0.76^{\mathrm{a}}$ & $3.84 \pm 0.75^{\mathrm{a}}$ & $3.88 \pm 0.83^{\mathrm{a}}$ & $3.96 \pm 1.06^{\mathrm{a}}$ \\
\hline AEO & $4.16 \pm 0.85^{\mathrm{a}}$ & $4.28 \pm 0.74^{\mathrm{a}}$ & $3.96 \pm 0.73^{\mathrm{a}}$ & $3.72 \pm 0.89^{\mathrm{a}}$ & $3.92 \pm 0.86^{\mathrm{a}}$ \\
\hline AEO washed & $4.12 \pm 0.93^{\mathrm{a}}$ & $4.28 \pm 1.06^{\mathrm{a}}$ & $3.88 \pm 0.88^{\mathrm{a}}$ & $3.92 \pm 0.91^{\mathrm{a}}$ & $3.60 \pm 1.04^{\mathrm{a}}$ \\
\hline $\mathrm{AEO}+L$ & $3.76 \pm 0.88^{\mathrm{a}}$ & $3.88 \pm 0.78^{\mathrm{a}}$ & $3.48 \pm 1.08^{\mathrm{a}}$ & $3.64 \pm 1.04^{\mathrm{a}}$ & $3.40 \pm 0.96^{\mathrm{a}}$ \\
\hline AEO washed $+L$ & $4.16 \pm 0.80^{\mathrm{a}}$ & $4.20 \pm 0.87^{\mathrm{a}}$ & $3.76 \pm 0.97^{\mathrm{a}}$ & $3.40 \pm 1.08^{\mathrm{a}}$ & $3.60 \pm 0.82^{\mathrm{a}}$ \\
\hline
\end{tabular}

${ }^{a}$ Mean \pm SD, $n=25$; values in the same column for each attribute followed by a different letter (a-d) are significantly different $(p<0.05)$. AEO: acidic electrolyzed oxidizing (AEO) water $(100 \mathrm{mg} / \mathrm{kg})$ treatment for $5 \mathrm{~min}$. AEO washed: acidic electrolyzed oxidizing water treatment for 5 min followed by washing. $\mathrm{AEO}+L$ : electrolyzed oxidizing water treatment for $5 \mathrm{~min}$ followed by spraying of $0.5 \%$ lysozyme enzyme $(L)$ solution. AEO washed $+L$ : electrolyzed oxidizing water treatment for $5 \mathrm{~min}$ followed by washing and spraying of $0.5 \%$ lysozyme enzyme solution on the total viable count of carp samples.

3.2. Residual Chlorate and Perchlorate Content. As the chlorate and perchlorate concentration of the samples after AEO water treatment was reported to be negligible in vacuum packaged conditions, it was measured immediately after the treatment [33]. As Table 4 shows, the residual chlorate and perchlorate contents of samples treated with AEO water were high, exceeding the permitted limit of chlorate of $0.01 \mathrm{mg} / \mathrm{kg}$ and also the MRL of $0.7 \mathrm{mg} / \mathrm{kg}$ suggested by EFSA [27].

However, the residual chlorate content of samples washed after the AEO water treatment was below the theoretical threshold limit value. According to the laboratory tests ordered by the European vegetable processors, it becomes clear that chlorate is already present in the drinking water; therefore, companies that do not use any chlorinated products in their process have also found chlorate residues close to or even exceeding the MRLs [36]. The difficulty of the compliance with the current legalization is represented on the chlorate concentrations measured on the control samples, exceeding the threshold limit after tap water washing.

3.3. Sensory Evaluation. The results of the sensory evaluation of the fish samples are presented in Table 5. There were no significant differences between all kinds of carp samples $(p<0.05)$, which indicated that applied treatment methods did not have a negative impact on the sensory quality of the carp samples. These results are in agreement with the data obtained following AEO water treatment of Pufferfish [37] and frozen shrimp samples [38], where the AEO water treatment did not have an adverse effect on the organoleptic properties.

\section{Conclusion}

The combination of AEO water and lysozyme enzyme showed additional bactericidal efficacy on the surface of the carp fillets, what has never been reported before. Compared to the AEO water treatment, the combined treatment caused further reduction in the number of spoiling microorganisms and effectively extended the shelf life of ultrafresh products by more than 5 days compared to the control group; thus its industrial application would have significant economic benefits. No combination of treatment showed to influence the organoleptic properties of the samples. The application of acidic water on its own or combined with other substances may prolong the shelf life of carp fillets from microbiological point of view, but the amount of residual chlorate exceeds the permitted limit value stored in closed vacuum packaged conditions. Although washing the samples after the acidic electrolyzed oxidizing water treatment resulted in lower effectiveness, the residual chlorate content of samples was below the theoretical threshold limit value. Furthermore, the application of lysozyme enzyme successfully compensated the loss of effectiveness caused by the washing step. Nevertheless, it is advisable to conduct further studies in order to optimize the method of acidic active water application with particular regard to its effect on extended shelf life and the quantity of residual chlorate exceeding the threshold limit. 


\section{Data Availability}

The datasets used to support the findings of this study are included within the article.

\section{Conflicts of Interest}

The authors declare that they have no conflicts of interest.

\section{Acknowledgments}

This study was supported by the NVKP_16-1-2016-0023 project funded by the National Research, Development and Innovation Fund.

\section{References}

[1] J. H. J. Huis In't Veld, "Microbial and biochemical spoilage of foods: an overview," International Journal of Food Microbiology, vol. 33, no. 1, pp. 1-18, 1996.

[2] H. Winker, O. L. F. Weyl, A. J. Booth, and B. R. Ellender, "Validating and corroborating the deposition of two annual growth zones in asteriscus otoliths of common carp Cyprinus carpio from South Africa's largest impoundment," Journal of Fish Biology, vol. 77, no. 10, pp. 2210-2228, 2010.

[3] FAO, FAO Yearbook. Fishery and Aquaculture Statistics 2016, Food and Agriculture Organization of the United Nations, Rome, Italy, 2018.

[4] B. S. M. Mahmoud, K. Yamazaki, K. Miyashita, S. Il-Shik, C. Dong-Suk, and T. Suzuki, "Decontamination effect of electrolysed $\mathrm{NaCl}$ solutions on carp," Letters in Applied Microbiology, vol. 39, no. 2, pp. 169-173, 2004.

[5] G. W. Suzuki, "Industry perspectives on the use of natural antimicrobials and inhibitors for food applications," Journal of Food Protection, vol. 59, no. 13, pp. 82-86, 1996.

[6] B. S. M. Mahmoud, "Electrolyzed water: a new technology for food decontamination-a review," Deutsche Lebensmittel-Rundschau, vol. 103, no. 5, pp. 212-221, 2007.

[7] X. Xuan and J. Ling, "Generation of electrolyzed water," Electrolyzed Water in Food: Fundamentals and Applications, pp. 1-16, Springer Nature Singapore Pte Ltd. and Zhejiang University Press, Hangzhou, China, 2019.

[8] I. Machado, A. Meireles, R. Fulgêncio, F. Mergulhão, M. Simões, and L. F. Melo, "Disinfection with neutral electrolyzed oxidizing water to reduce microbial load and to prevent biofilm regrowth in the processing of fresh-cut vegetables," Food and Bioproducts Processing, vol. 98, pp. 333-340, 2016.

[9] Y.-R. Huang, Y.-C. Hung, S.-Y. Hsu, Y.-W. Huang, and D.-F. Hwang, "Application of electrolyzed water in the food industry," Food Control, vol. 19, no. 4, pp. 329-345, 2008.

[10] R. Hwang, Z. Mingming, W. Chen et al., "A hurdle approach of acidic electrolyzed water simultaneous with ultrasound to inactivate Bacillus cereus," Journal of Food Processing and Preservation, vol. 43, pp. 1-8, 2019.

[11] S.-V. Len, Y.-C. Hung, M. Erickson, and C. Kim, "Ultraviolet spectrophotometric characterization and bactericidal properties of electrolyzed oxidizing water as influenced by amperage and pH," Journal of Food Protection, vol. 63, no. 11, pp. 1534-1537, 2000.

[12] B. S. M. Mahmoud, K. Yamazaki, K. Miyashita, S. Il-Shik, C. Dong-Suk, and T. Suzuki, "Bacterial microflora of carp (Cyprinus carpio) and its shelf-life extension by essential oil compounds," Food Microbiology, vol. 21, no. 6, pp. 657-666, 2004b.

[13] Q. Liu, L. Chen, A. K. C. Laserna et al., "Synergistic action of electrolyzed water and mild heat for enhanced microbial inactivation of Escherichia coli O157: H7 revealed by metabolomics analysis," Food Control, vol. 110, p. 107026, 2020.

[14] N. Ebran, S. Julien, N. Orange, B. Auperin, and G. Molle, "Isolation and characterization of novel glycoproteins from fish epidermal mucus: correlation between their pore-forming properties and their antibacterial activities," Biochimica et Biophysica Acta (BBA)-Biomembranes, vol. 1467, no. 2, pp. 271-280, 2000.

[15] S. Phuvasate and Y.-C. Su, "Effects of electrolyzed oxidizing water and ice treatments on reducing histamine-producing bacteria on fish skin and food contact surface," Food Control, vol. 21, no. 3, pp. 286-291, 2010.

[16] M. Jana, A. Ghosh, A. Santra, R. K. Kar, A. K. Misra, and A. Bhunia, "Synthesis of novel muramic acid derivatives and their interaction with lysozyme: action of lysozyme revisited," Journal of Colloid and Interface Science, vol. 498, pp. 395-404, 2017.

[17] D. Nakimbugwe, B. Masschalck, G. Anim, and C. W. Michiels, "Inactivation of gram-negative bacteria in milk and banana juice by hen egg white and lambda lysozyme under high hydrostatic pressure," International Journal of Food Microbiology, vol. 112, no. 1, pp. 19-25, 2006.

[18] M. S. Rao, R. Chander, and A. Sharma, "Synergistic effect of chitooligosaccharides and lysozyme for meat preservation," LWT-Food Science and Technology, vol. 41, no. 10, pp. 1995-2001, 2008.

[19] F. Nattress and L. P. Baker, "Effects of treatment with lysozyme and nisin on the microflora and sensory properties of commercial pork," International Journal of Food Microbiology, vol. 85, no. 3, pp. 259-267, 2003.

[20] X. Bi, X. Wang, Y. Chen, L. Chen, Y. Xing, and Z. Che, "Effects of combination treatments of lysozyme and high power ultrasound on the Salmonella typhimurium inactivation and quality of liquid whole egg," Ultrasonics Sonochemistry, vol. 60, p. 104763, 2020.

[21] S. Nakamura, A. Kato, and K. Kobayashi, "Bifunctional lysozyme-galactomannan conjugate having excellent emulsifying properties and bactericidal effect," Journal of Agricultural and Food Chemistry, vol. 40, no. 5, pp. 735-739, 1992.

[22] J. K. Branen and P. M. Davidson, "Enhancement of nisin, lysozyme, and monolaurin antimicrobial activities by ethylenediaminetetraacetic acid and lactoferrin," International Journal of Food Microbiology, vol. 90, no. 1, pp. 63-74, 2004.

[23] R. Cegielska-Radziejewska, G. Leśnierowski, and J. Kijowski, "Properties and application of egg white lysozyme and its modified preparations-a review," Polish Journal of Food and Nutrition Sciences, vol. 58, no. 1, pp. 5-10, 2008.

[24] D. Couri, M. S. Abdel-Rahman, and R. J. Bull, "Toxicological effects of chlorine dioxide, chlorite and chlorate," Environmental Health Perspectives, vol. 46, no. 5, pp. 13-17, 1982.

[25] D. Hamilton, Ám Ambrus, R. Dieterle et al., "Pesticide residues in food-acute dietary exposure," Pest Management Science, vol. 60, no. 4, pp. 311-339, 2004.

[26] Gonzalez, Regulation (EC) No 396/2005 of the European Parliament and of the Council of 23 February 2005 on Maximum Residues Levels of Pesticides in or on Food and Feed of Plant and Animal Origin and Amending Council Directive 91/414/EC, vol. L 70, pp. 1-16, European Commission, Brussels, Belgium, 2005. 
[27] EFSA, "Risks for public health related to the presence of chlorate in food," EFSA Journal, vol. 13, no. 6, pp. 1-103, 2015.

[28] M. Anastassiades, D. I. Kolberg, D. Mack, C. Wildgrube, I. Sigalov, and D. Dörk, Quick Method for the Analysis of Residues of Numerous Highly Polar Pesticides in Foods of Plant Origin Involving Simulta- Neous Extraction with Methanol and LC-MS/MS Determination, pp. 1-44, European Commission, Brussels, Belgium, 2013.

[29] K. Broekaert, M. Heyndrickx, L. Herman, F. Devlieghere, and G. Vlaemynck, "Seafood quality analysis: molecular identification of dominant microbiota after ice storage on several general growth media," Food Microbiology, vol. 28, no. 6, pp. 1162-1169, 2011.

[30] G. Xu, X. Tang, S. Tang, H. You, H. Shi, and R. Gu, "Combined effect of electrolyzed oxidizing water and chitosan on the microbiological, physicochemical, and sensory attributes of American shad (Alosa sapidissima) during refrigerated storage," Food Control, vol. 46, pp. 397-402, 2014.

[31] A. M. Abdou, M. Kim, and K. Sato, Functional Proteins and Peptides of Hen's Egg Origin-Bioactive Food Peptides in Health and Disease, pp. 115-144, IntechOpen, London, UK, 2013.

[32] W. Chung and R. E. W. Hancock, "Action of lysozyme and nisin mixtures against lactic acid bacteria," International Journal of Food Microbiology, vol. 60, no. 1, pp. 25-32, 2000.

[33] S.-V. Len, Y.-C. Hung, D. Chung, J. L. Anderson, M. C. Erickson, and K. Morita, "Effects of storage conditions and $\mathrm{pH}$ on chlorine loss in electrolyzed oxidizing (EO) water," Journal of Agricultural and Food Chemistry, vol. 50, no. 1, pp. 209-212, 2002.

[34] Y.-R. Huang, H.-S. Hsieh, S.-Y. Lin, S.-J. Lin, Y.-C. Hung, and D.-F. Hwang, "Application of electrolyzed oxidizing water on the reduction of bacterial contamination for seafood," Food Control, vol. 17, no. 12, pp. 987-993, 2006.

[35] N. P. Ozer and A. Demirci, "Electrolyzed oxidizing water treatment for decontamination of raw salmon inoculated with Escherichia coli O157 : H7 and Listeria monocytogenes Scott A and response surface modeling," Journal of Food Engineering, vol. 72, no. 3, pp. 234-241, 2006.

[36] PROFEL, PROFEL Position Paper on Chlorates, European Association of Fruit and Vegetable Processors, Brussel, Belgium, 2018.

[37] R. Zhou, Y. Liu, J. Xie, and X. Wang, "Effects of combined treatment of electrolysed water and chitosan on the quality attributes and myofibril degradation in farmed obscure puffer fish (Takifugu obscurus) during refrigerated storage," Food Chemistry, vol. 129, no. 4, pp. 1660-1666, 2011.

[38] M. H. Loi-Braden, T.-S. Huang, J.-H. Kim, C.-I. Wei, and J. Weese, "Use of electrolyzed oxidizing water for quality improvement of frozen shrimp," Journal of Food Science, vol. 70, no. 6, pp. m310-m315, 2005. 